\title{
Notes for Contributors
}

The Journal of Anglican Studies is an international, fully refereed journal that publishes articles and reviews current work in the study of Anglicanism. The journal publishes occasional thematic articles on special topics. Correspondence about potential topics for future thematic issues should be directed to the Editor (after May 2021 brian.douglas@mac.com).

Full Guidelines for Contributors can be found on the website of the Journal: cambridge.org/ast

Publishers are invited to send details of books for review to the Review Editor, The Right Revd Dr Stephen Platten (stephen.platten@icloud.com) who will identify the reviewer. The publisher will be asked to send the book directly to the reviewer identified by the Review Editor.

The Editor welcomes articles for publication in the Journal. Submissions should be made online at https://www.cambridge.org/core/journals/journal-of-anglican-studies

Manuscripts should be formatted using one-and-a-half line spacing, and numbered consecutively throughout. Submissions should include a cover sheet, preferably letter head, with the title of the paper, name and title of the author, institutional affiliation and teaching or research post (if relevant), postal address, telephone, fax and email. If accepted for peer review, papers will be assessed anonymously. Except for the cover sheet, all identification should be removed.

All articles will be refereed and should normally be 5000-8000 words in length. A short abstract of 50-150 words and six to eight keywords MUST be supplied with your article.

Illustrations, tables, maps and figures must be numbered consecutively and include captions which identify the source of any image or data. Authors are responsible for obtaining and paying for all copyright and reproduction charges. Preferred formats for figures are tif or eps files, jpegs can also be accepted for photographs (halftones), but these may not print as well as you expect. If text labels are required as part of the jpeg halftone it should be imported into illustration software for labelling and saved as an eps file. All files must be a minimum of $300 \mathrm{dpi}$ (dots per inch) for halftones, $600 \mathrm{dpi}$ for combination figures and 1200 dpi for line art (black and white). Colour files must be supplied as CMYK (not RGB) at a minimum resolution of $300 \mathrm{dpi}$. Note that the image size must be no smaller than the size at which it will appear in the journal. Please do not submit your figures embedded into Word documents as the quality will be severely degraded.

The first-named author will receive a complimentary copy of the journal plus an email giving them a link to a PDF of their article.

Journal of Anglican Studies is covered by the following abstracting and indexing services: Thomson Reuters Arts and Humanities Citation Index, ATLA Religion Database ${ }^{\circledR}$ (ATLA RDB ${ }^{\circledR}$ ), Scopus, Current Abstracts (EBSCO Publishing), Swets Information Services, Index Theologicus, Religious and Theological Abstracts, European Reference Index for the Humanities and Social Sciences (ERIH PLUS), New Testament Abstracts, JISC Journal TOCs (Contents alerting system), Google Scholar

This journal issue has been printed on FSC-certified paper and cover board. FSC is an independent, non-governmental, not-for-profit organization established to promote the responsible management of the world's forests. Please see www.fsc.org for information. 


\section{Journal of \\ Anglican Studies}

\section{Volume 19.2 November 2021}

\section{Contents}

\section{Editorial}

Guest Editorial

Stephen Pickard

\section{Articles}

Enhancing the Safety of All Persons within the Anglican Communion: Initiatives of the Instruments of Communion

Garth Blake

Anglican Church of Southern Africa: Safe and Inclusive Church Commission Rosalie Manning, Colette Saldanha, Claire Phelps, Chris Ahrends and Peter Lee

Diocesanism versus Australia's Royal Commission into Institutional Responses to Child Sexual Abuse

Alison M. Taylor

Pastoral Supervision for Safe Churches

Geoff Broughton

Child Sexual Abuse, Integrity Systems and the Anglican Church: Truth, Justice and Love

Virginia Miller and Seumas Miller

Book Reviews 